ATOLL RESEARCH BULLETIN

NO. 478

GNATHOSTOMULIDA IN THE PELICAN CAYS, BELIZE

BY

WOLFGANG STERRER

ISSUED BY

NATIONAL MUSEUM OF NATURAL HISTORY

SMITHSONIAN INSTITUTION

WASHINGTON, D.C., U.S.A.

MARCH 2000 


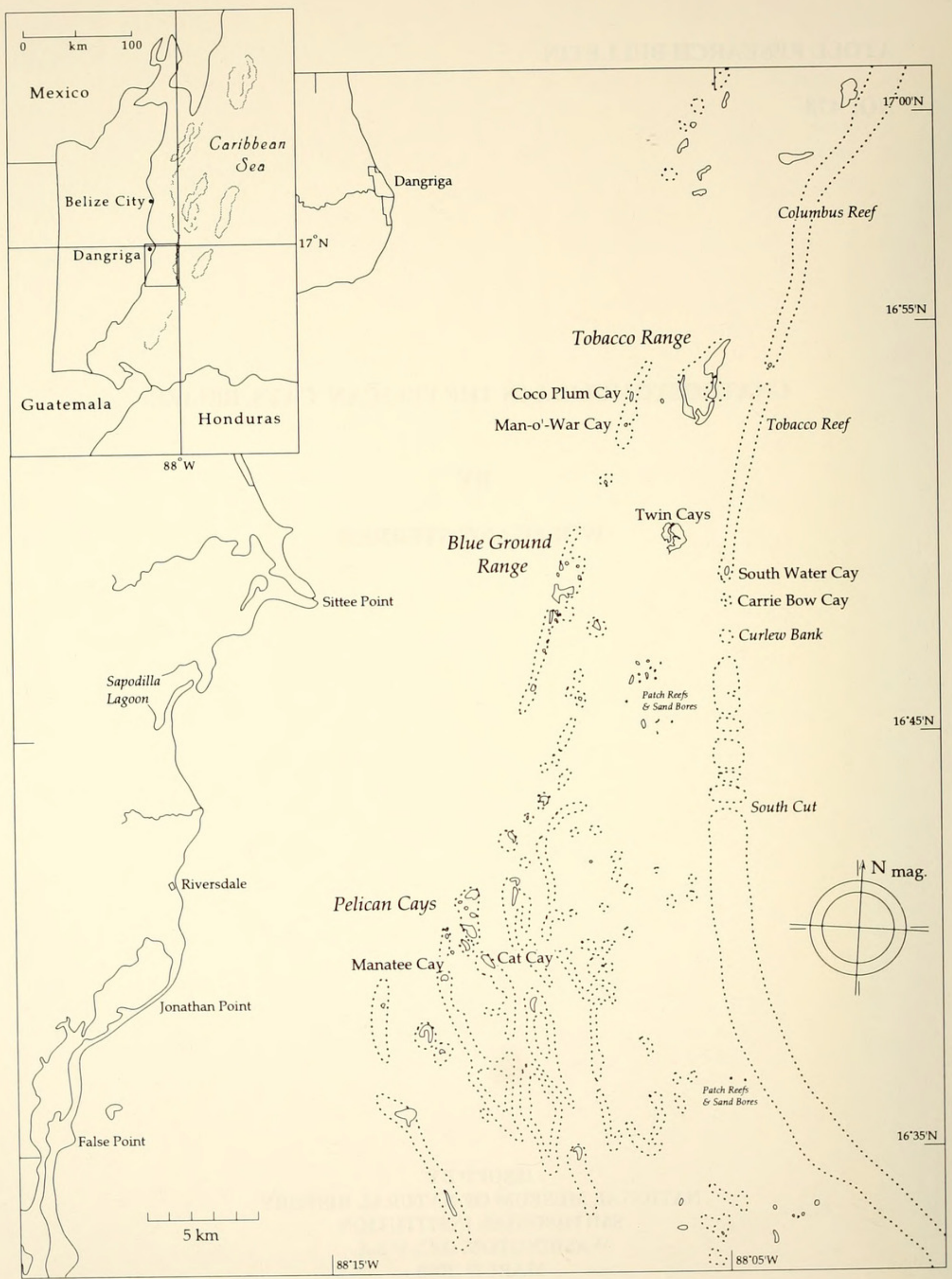

Figure 1. Index map showing sample sites. 


\title{
GNATHOSTOMULIDA IN THE PELICAN CAYS, BELIZE
}

\author{
BY \\ WOLFGANG STERRER ${ }^{1}$
}

\begin{abstract}
Gnathostomulida, a small phylum of microscopic, sand-dwelling marine worms, appear to be particularly well represented in the coarse yet detritus-rich sediments that typically occur where coral reefs meet seagrasses or mangroves. Of 25 species encountered in 35 sediment samples collected in southern Belize between 1974 and 1997, 14 species were extracted from only two samples from the Pelican Cays.
\end{abstract}

\section{INTRODUCTION}

Gnathostomulida are unsegmented, acoelomate, small (1-3 mm long) worms that live in the interstices of marine sand. First described as aberrant Turbellaria (Ax, 1956), they were subsequently promoted to the rank of phylum (Riedl, 1969; Sterrer, 1972) on the basis of a unique combination of anatomical features, particularly a monociliary epidermis (each epidermal cell carries only a single cilium), and a bilaterally symmetric pharynx equipped with complex cuticular mouth parts. Found exclusively, sometimes in large numbers, in shallow, detritus-rich marine sand, Gnathostomulida are presumed to feed by grazing on the bacterial and fungal microflora that coats sand grains. In addition to very low oxygen requirements, they may have mechanisms for sulfide detoxification. Only 91 species, in 25 genera, are currently known worldwide (Sterrer, 1998), many with cosmopolitan distribution. Gnathostomulida may be the most primitive living Bilateria (Ax, 1986; Sterrer et al., 1985), yet their phylogenetic affinities remain enigmatic.

Between 1974 and 1997, I visited the Carrie-Bow Cay field station in southern Belize (Rützler and Macintyre, 1982) six times and collected 88 sediment samples, which yielded a total of 25 species of Gnathostomulida (including 7 species and 2 genera new to science), the largest number from any area in the world (Sterrer, 1998). Most samples came from the immediate vicinity of Carrie-Bow Cay (see Fig. 1), either from shallow sand between patch reefs and Thalassia or from deep sand troughs in the fore-reef area. The nearby mangrove island of Twin Cays was sampled repeatedly. Sand from the base of the Southern Sandbores, curious coneshaped islets within the lagoon, produced the type specimens of Clausognathia suicauda Sterrer, 1992.

'Bermuda Natural History Museum, Flatts FLBX, Bermuda; e-mail wsterrer@sargasso.bbsr.edu. 


\section{METHODS}

The method of collecting and specimen extraction (for details see Sterrer, 1998) allows some crude observations on species richness (Sterrer, 1971). Using snorkeling or scuba, the upper $5 \mathrm{~cm}$ of sediment are scooped into a bucket by hand until the latter is full; a primary sample thus consists of about 10-15 liters of sand, with a little overlying seawater. In the lab, this primary sample is periodically subsampled by scooping the superficial layer of sand (about 500 $\mathrm{ml}$ ) into a flask and shaking it in an isotonic magnesium sulfate solution. The floating meiofauna is then poured through a $63 \mu \mathrm{m}$ sieve and allowed to recover before it is sorted to species and analyzed under the phase-contrast microscope. Extraction ends when the sample ceases to produce gnathostomulids, usually after $7-12$ days.

\section{RESULTS}

All samples were collected with the specific objective of finding Gnathostomulida, which means they came from sheltered sandy (not muddy) bottoms with a high content of marine (not terrigenic) detritus, as is typically found in the vicinity of seagrasses, mangroves, and between coral reefs. In their preferred environment, Gnathostomulida are often represented by up to a dozen species per sample, whereas marginal environments (i.e., sand that is either too clean or too clogged with terrigenous detritus) may contain only one species, often of the eurytopic genus Gnathostomula (unpublished observations). Representative morphological types of these worms are shown in Figure 2.

Of a total of 88 samples taken between 1974 and 1997 (Table 1), 35 samples (40\%) were positive, each containing at least one, and at most 10, species. Over the period May 5-16, 1994, I collected 24 samples ( 6 at Coco Plum Cay, 5 at Twin Cays, 2 at Southern Sand Bores, 1 at Mano'War Cay, 7 off Carrie-Bow Cay, and 3 at Pelican Cays). Of these, 14 samples (58\%) yielded Gnathostomulida.

The following three samples were collected in the Pelican Cays:

\#94.9: coll. May 7, 1994, off Cat Cay; small sand hole in reef flat off red mangrove, $2 \mathrm{~m}$ \#94.14: coll. May 12, 1994, off Cat Cay; heterogeneous Halimeda sand from two sand troughs in reef ridge, $2 \mathrm{~m}$

\#94.15: coll. May 12, 1994, at S end of Manatee Cay; medium to coarse sand in sparse, short Thalassia, $1.5 \mathrm{~m}$.

Two of these samples (94.9 and 94.15) were positive (67\%), yielding 8 and 10 species, respectively, or a total of 14 species. This high species richness per positive Pelican Cays sample compares favorably with the remaining 12 positive samples of the 1994 collecting season, which together produced only 7 species ( 0.58 spp. per sample). Of 25 species recorded from Belize, three (Pterognathia alcicornis, P. crocodilus, and P. ctenifera) were found exclusively in the Pelican Cays samples.

The remarkable species richness of Gnathostomulida in the Pelican Cays may be due to the composition of the sediment — coarse coral sand admixed with flocculent detritus - itself the result of the close proximity of coral reef, seagrasses, and mangrove ("mangreef"). 


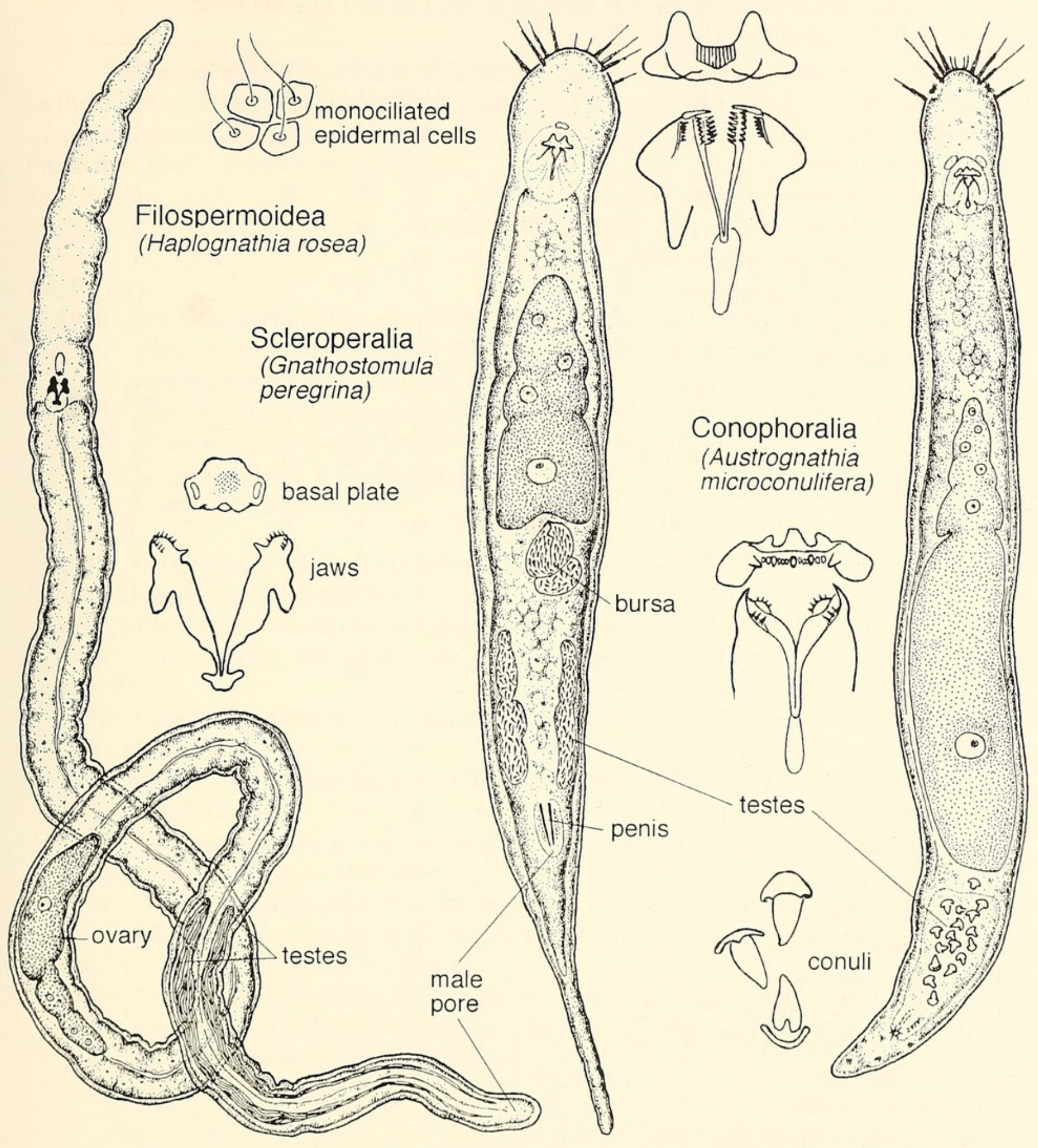

Figure 2. Representative Gnathostomulida of the order Filospermoidea, and the suborders Scleroperalia and Conophoralia. Size range of these interstitial worms is 1-3 mm long. 
Table 1. Comparison of Gnathostomulida sampled at The Pelican Cays and other locations in Belize between 1974 and 1997.

\begin{tabular}{|c|c|c|c|c|c|c|}
\hline \multirow[b]{2}{*}{ Taxa and Parameters } & \multicolumn{3}{|c|}{ Pelican Cays, 1994} & \multicolumn{2}{|c|}{ Other Belize } & \multirow{2}{*}{$\begin{array}{r}\text { Belize } \\
\text { total }\end{array}$} \\
\hline & 94.9 & 94.15 & total & 1994 & total & \\
\hline \multicolumn{7}{|l|}{ Order Filospermoidea } \\
\hline \multicolumn{7}{|l|}{ Family Haplognathiidae } \\
\hline \multirow{5}{*}{$\begin{array}{l}\text { Haplognathia } \text { asymmetrica } \text { Sterrer, } 1991 \\
\text { belizensis } \text { Sterrer, } 1998 \\
\\
\text { lunulifera }(\text { Sterrer, 1969) } \\
\text { rosea }(\text { Sterrer, 1969) } \\
\text { ruberrima }(\text { Sterrer, 1966) }\end{array}$} & 0 & 3 & 3 & 0 & 3 & 6 \\
\hline & 0 & 0 & 0 & 0 & 2 & 2 \\
\hline & 0 & 0 & 0 & 0 & 1 & 1 \\
\hline & 0 & 0 & 0 & 3 & 12 & 12 \\
\hline & 1 & 1 & 2 & 0 & 13 & 15 \\
\hline \multicolumn{7}{|l|}{ Family Pterognathiidae } \\
\hline \multirow[t]{3}{*}{ Cosmognathia aquila Sterrer, 1998} & 0 & 2 & 2 & 6 & 18 & 20 \\
\hline & 0 & 0 & 0 & 0 & 1 & 1 \\
\hline & 0 & 1 & 1 & 0 & 1 & 2 \\
\hline Pterognathia alcicornis Sterrer, 1998 & 1 & 0 & 1 & 0 & 0 & 1 \\
\hline crocodilus Sterrer, 1991 & 1 & 0 & 1 & 0 & 0 & 1 \\
\hline ctenifera Sterrer, 1969 & 0 & 7 & 7 & 0 & 0 & 7 \\
\hline swedmarki Sterrer, 1966 & 0 & 0 & 0 & 0 & 1 & 1 \\
\hline ugera Sterrer, 1991 & 9 & 0 & 9 & 0 & 6 & 15 \\
\hline \multicolumn{7}{|l|}{ Order Bursovaginoidea } \\
\hline \multicolumn{7}{|l|}{ Suborder Scleroperalia } \\
\hline \multicolumn{7}{|l|}{ Family Clausognathiidae } \\
\hline Clausognathia suicauda Sterrer, 1992 & 1 & 0 & 1 & 0 & 10 & 11 \\
\hline Labidognathia longicollis Riedl, 1970 & 0 & 1 & 1 & 0 & 7 & 8 \\
\hline Tenuignathia rikerae Sterrer, 1976 & 0 & 0 & 0 & 1 & 17 & 17 \\
\hline \multicolumn{7}{|l|}{ Family Paucidentulidae } \\
\hline Paucidentula anonyma Sterrer, 1998 & 0 & 1 & 1 & 0 & 6 & 7 \\
\hline \multicolumn{7}{|l|}{ Family Onychognathiidae } \\
\hline Onychognathia rhombocephala Sterrer, 1998 & 0 & 0 & 0 & 1 & 15 & 15 \\
\hline \multicolumn{7}{|l|}{ Family Gnathostomulidae } \\
\hline Gnathostomula axi Kirsteuer, 1964 & 0 & 0 & 0 & 0 & 11 & 11 \\
\hline peregrina Kirsteuer, 1969 & 1 & 1 & 2 & 0 & 10 & 12 \\
\hline Suborder Conophoralia & & & & & & \\
\hline Family Austrognathiidae & & & & & & \\
\hline Austrognathia christianae Farris, 1977 & 0 & 2 & 2 & 0 & 19 & 21 \\
\hline microconulifera Farris, 1977 & 1 & 1 & 2 & 2 & 10 & 12 \\
\hline Austrognatharia medusifera Sterrer, 1998 & 0 & 0 & 0 & 3 & 8 & 8 \\
\hline sterreri (Kirsteuer, 1969) & 0 & 0 & 0 & 0 & 8 & 8 \\
\hline strunki Farris, 1973 & 0 & 0 & 0 & 8 & 8 & 8 \\
\hline Total positive samples & 1 & 1 & 2 & 12 & 33 & 35 \\
\hline Total specimens & 15 & 20 & 35 & 24 & 187 & 222 \\
\hline Total species & 7 & 10 & 14 & 7 & 22 & 25 \\
\hline Species per sample & 7.00 & 10.00 & 7.00 & 0.58 & 0.67 & 0.71 \\
\hline
\end{tabular}




\section{ACKNOWLEDGMENTS}

I am indebted to Klaus Rützler and Mike Carpenter for providing such congenial field facilities on the doorstep to near-pristine marine ecosystems. Fieldwork for this project was supported by the U.S. National Museum of Natural History's Caribbean Coral Reef Ecosystems Program (CCRE Contribution No. 588).

\section{REFERENCES}

$\mathrm{Ax}, \mathrm{P}$.

1956. Die Gnathostomulida, eine rätselhafte Wurmgruppe aus dem Meeressand. Abhandlungen der Akademie der Wissenschaften und Literatur Mainz, mathematischnaturwissenschaftliche Klasse, 8:1-32.

1986. The position of the Gnathostomulida and Platyhelminthes in the phylogenetic system of the Bilateria. In The Origins and Relationships of Lower Invertebrates, edited by S. Conway Morris, J. D. George, R. Gibson, and H. M. Platt, 168-180. Oxford: Clarendon Press.

Riedl, R. J.

1969. Gnathostomulida from America. Science 163:445-442.

Rützler, K., and I. G. Macintyre (eds.)

1982. The Atlantic Barrier Reef Ecosystem at Carrie Bow Cay, Belize, I. Structure and Communities. Washington, DC: Smithsonian Institution Press, 539 p.

Sterrer, W.

1971. Gnathostomulida: Problems and procedures. Smithsonian Contributions to Zoology 76:9-15.

1972. Systematics and evolution within the Gnathostomulida. Systematic Zoology 21(2):151-173.

1992. Clausognathiidae, a new family of Gnathostomulida from Belize. Proceedings of the Biological Society of Washington 105(1):136-142.

1998. Gnathostomulida from the (sub)tropical northwestern Atlantic. Studies on the Natural History of the Caribbean Region 74:1-178.

Sterrer, W., M. Mainitz, and R. M. Rieger

1985. Gnathostomulida: Enigmatic as ever. In The Origins and relationships of lower invertebrates, edited by S. Conway Morris, J. D. George, R. Gibson, and H. M. Platt, 183-199. Oxford: Clarendon Press. 


\section{$2 \mathrm{BHL}$ Biodiversity Heritage Library}

Sterrer, Wolfgang. 2000. "Gnathostomulida in the Pelican Cays, Belize." Atoll research bulletin $478,265-271$.

View This Item Online: https://www.biodiversitylibrary.org/item/123419

Permalink: https://www.biodiversitylibrary.org/partpdf/83131

\section{Holding Institution}

Smithsonian Libraries

\section{Sponsored by}

Biodiversity Heritage Library

\section{Copyright \& Reuse}

Copyright Status: In Copyright. Digitized with the permission of the rights holder Rights Holder: National Museum of Natural History, Smithsonian Institution License: https://creativecommons.org/licenses/by-nc-sa/4.0/ Rights: http://www.biodiversitylibrary.org/permissions/

This document was created from content at the Biodiversity Heritage Library, the world's largest open access digital library for biodiversity literature and archives. Visit BHL at https://www.biodiversitylibrary.org. 